\title{
Comparison of Drosophilidae (Diptera) assemblages from two highland Araucaria Forest fragments, with and without environmental conservation policies
}

\author{
Cavasini, R. ${ }^{a}$, Buschini, MLT. ${ }^{a}$, Machado, LPB. ${ }^{a}$ and Mateus, RP. ${ }^{a *}$ \\ aPrograma de Pós-graduação em Biologia Evolutiva, Departamento de Ciências Biológicas, Universidade Estadual do \\ Centro-Oeste - UNICENTRO, Rua Simeão Camargo Varela de Sá, 3, CEP 85040-080, Guarapuava, PR, Brazil \\ *e-mail: rogeriopmateus@gmail.com
}

Received: January 31, 2013 - Accepted: July 29, 2013 - Distributed: December 31, 2014

(With 1 figure)

\begin{abstract}
Flies from the Drosophilidae family are model organisms for biological studies and are often suggested as bioindicators of environmental quality. The Araucaria Forest, one of Atlantic Forest phyto-physiognomy, displays a highly fragmented distribution due to the expansion of agriculture and urbanization. Thus, this work aimed to evaluate and compare the drosophilid assemblages from two highland Araucaria Forest fragments, one a conservation unit (PMA - Parque Municipal das Araucárias) and the other a private property without any conservational policy (FBL - Fazenda Brandalise), in space and time, using species abundances and richness, ecological indexes and Neotropical and exotic species proportions as parameters to establish the level of environmental quality of these fragments. Our results showed that the observed diversity in PMA $\left(H^{\prime}=2.221\right)$ was approximately $40 \%$ higher than in FBL $\left(H^{\prime}=1.592\right)$. This could be due to higher preservation quality and habitat diversity in PMA, indicating the importance of conservation units. However, richness were similar for these areas, with PMA $\left(D_{m g}=6.602\right)$ only $8 \%$ higher than FBL $\left(D_{m g}=6.128\right)$, which suggest that the larger distance from city limits and the larger size of FBL forested area could be compensating the higher disturbance caused by antrophic extractive exploitation of this fragment. This points out that, besides the quality of presevertion, the size and/or connection with other fragments should be considered for areas destined for biodiversity conservation. In general, both areas presented similar drosophilid assemblages, and the expressive abundance of both Neotropical species (mostly of the subgroup willistoni) and the exotic species $D$. kikkawai suggests that these areas are in intermediate stages of conservation.
\end{abstract}

Keywords: ecological indexes, Mixed Ombrophylous Forest, exotic species, Drosophila, Atlantic Forest, Neotropical region.

\section{Comparação das assembleias de Drosophilidae (Diptera) de dois fragmentos de floresta de araucária de altitude, com e sem políticas de conservação ambiental}

\section{Resumo}

Moscas da família Drosophilidae são organismos modelo para estudos biológicos e frequentemente sugeridas como bioindicadoras da qualidade ambiental. A Mata de Araucária, uma das fitofisionomias da Mata Atlântica, apresenta-se altamente fragmentada devido a expansão da agricultura e da urbanização. Assim, este trabalho teve como objetivo avaliar e comparar as assembleias de drosofilídeos de dois fragmentos de Mata de Araucária de altitude, uma área de preservação (PMA - Parque Municipal das Araucárias) e uma propriedade particular e sem política de conservação (FBL - Fazenda Brandalise), no tempo e no espaço, utilizando abundâncias e riquezas das espécies, índices ecológicos e proporções de espécies neotropicais e espécies exóticas como parâmetros para estabelecer o nível de qualidade ambiental destes fragmentos. Nossos resultados mostraram que a diversidade observada em PMA $\left(H^{\prime}=2,221\right)$ foi $40 \%$ maior do que em FBL $\left(H^{\prime}=1,592\right)$. Isto pode ser devido a maior qualidade de conservação e diversidade de habitats encontrados em PMA, indicando a importância das unidades de conservação. Contudo, os índices de riqueza foram similares para estas áreas, com PMA $\left(D_{m g}=6,602\right)$ sendo apenas $8 \%$ maior que FBL $\left(D_{m g}=6,128\right)$, o que sugere que a maior distância do entorno da cidade e a maior área de mata de FBL poderiam estar compensando o distúrbio ambiental causado pela exploração extrativista antrópica nesta área. Isto destaca que além da qualidade de preservação, o tamanho e/ou conexão com outros fragmentos deveriam ser considerados para áreas destinadas a conservação da biodiversidade. De maneira geral, ambas áreas amostradas apresentaram assembleias de drosofilídeos semelhantes, e a abundância expressiva tanto de espécies neotropicais (a maioria pertencente ao subgrupo willistoni) quanto da espécie exótica D. kikkawai sugere que estas áreas estão em estágio intermediário de conservação.

Palavras-chave: índices ecológicos, Floresta Ombrófila Mista, espécies exóticas, Drosophila, Mata Atlântica, região Neotropical. 


\section{Introduction}

The Mixed Ombrophylous Forest (with predominance of Araucaria angustifolia [Bertol.] Kuntze, being therefore also known as Araucaria Forest) is the main phytophysiognomy of the Brazilian southern region and is one of several physiognomies that belong to the Atlantic Forest biome, one of the hottest hotspots of biodiversity in the planet (Myers et al., 2000). The current use of land has transformed the planet and shows the vital importance of the identification of the effects of fragmentation and human impact on tropical ecosystems as these have the largest proportions of the global biodiversity (Bawa et al., 2004).

The Araucaria Forest has been the focus of researches because of its vegetation coverage was reduced to about $12 \%$ of its original distribution (Ribeiro et al., 2009), and according to reports of the environmental Brazilian governmental agency (Brasil, 2010), the Guarapuava municipality is among the twelve cities that suppressed more the Atlantic Forest native vegetation between 2002 and 2008. In this context, this phyto-physiognomy displays a highly fragmented distribution due to the expansion of agricultural practices and urbanization. The most immediate effect of fragmentation is the loss of regional fauna and changes in species abundance, although several others may occur (Alford and Richards, 1999; Gibbs and Stanton, 2001). Contrasting with the antrophic action velocity, our knowledge about the community composition and the populational responses to fragmentation in these fragments are scarce.

The assessment of the effects of habitat fragmentation is routinely approached using species or groups of species as bioindicators of the environmental quality. Flies from the Drosophilidae have been often suggested as appropriated for these approaches (e.g., Parsons, 1991; Avondet et al., 2003; Mata et al., 2008, 2010). Multiple aspects make members of this family an excellent model, as described by Powell (1997): they are small, numerous, with a short life cycle, easily collected and manipulated, besides being extremely sensitive to changes in their habitat conditions. Some studies have reported that the relative abundance of Drosophilidae exotic species, usually cosmopolitan and associated with antrophic environments, presents a significant increase that corresponds to the increase in the level of urbanization (e.g., Avondet et al., 2003; Ferreira and Tidon, 2005; Gottschalk et al., 2007; Poppe et al., 2012). On the other hand, the frequency of indigenous and forest associated species decreases in these conditions, and some of them become absent in altered locations. Despite the knowledge that the Drosophilidae assemblages present a consistent pattern in response to a disturbance gradient, almost no research has been conducted in the highland Araucaria Forests of southern Brazil.

This work is pioneer in the analyses of Drosophilidae fauna from highland Araucaria Forests fragments in southern Brazil. Thus, our aim was to evaluate and compare the assemblages from two highland Araucaria Forest fragments, one a conservation unit and the other a private property without a conservational policy, in space and time, using species abundances and richness, ecological indexes and Neotropical and exotic species proportions as parameters to establish the level of environmental quality of these fragments.

\section{Material and Methods}

The areas of collection are highland (at about 1,100 m above the sea level) Araucaria Forest fragments located in the municipality of Guarapuava, Paraná State, Brazil. This region is characterized by a wet, cool seasoning, and during the warmest months the average temperature is below $22{ }^{\circ} \mathrm{C}$. Hoar frosts are common and severe in this region. The landscape in Guarapuava is composed mainly of Araucaria Forest and grasslands (Veloso et al., 1991). However, the grasslands have suffered high antrophic interference and the Araucaria Forest has been reduced to about $12 \%$ of its original size (Ribeiro et al., 2009), due to agriculture and wood exploration.

The collection areas are located about six kilometers apart from each other. The first one is a conservation unit since 1991 named Parque Municipal das Araucárias (PMA - 2523'36”S, 51 $27^{\circ}$ '19'W). It has 104 ha composed of Araucaria Forest (43 ha), grassland (6.8 ha), swamp (11.1 ha), riparian forest (10.1 ha) and altered areas (33 ha) (Buschini, 2006). It is opened for public visitation and the city limits and crop plantations surround this area. The second is a rural private property named Fazenda Brandalise (FBL

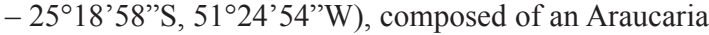
Forest fragment of about 400 ha surrounded only by crop plantations. This area has been under constant substitution of its natural environment by cultivated areas, in addition to an intense extractive activity (mate and Araucaria seeds).

The collections were performed in each season of 2006 (summer: February; autumn: May; winter: August; spring: December) and 2008 (summer: February; autumn: May; winter: August; spring: October) using 12 closed traps (modified from those described by Medeiros and Klaczko (1999), distributed in two transects $15 \mathrm{~m}$ apart (6 traps distant $40 \mathrm{~m}$ from each other in each transect). These transects were set inside the forest distant at least $100 \mathrm{~m}$ from the border in order to minimize its influence. All collections followed the same procedure: traps containing banana, orange and yeast baits, were set up at $1.5 \mathrm{~m}$ above the ground, and remained in the field for three days. After this period, collected flies were transferred directly from the traps into vials containing standard Drosophila culture medium, and transported to the laboratory. All specimens were identified based on the external morphology using taxonomic identification keys, species description and, for some cryptic groups, the male terminalia (Freire-Maia and Pavan, 1949; Frota-Pessoa, 1954; Val, 1982; Vilela, 1983, 1992; Vilela and Bächli, 1990). The females of these groups were identified at the group level. For the subgroup willistoni, which presents cryptic species, both males and females were identified to the subgroup level.

The number of sampled species $(S)$ and the total abundance of sampled individuals for each species $(N)$ were 
recorded for all collections. These parameters were used to estimate the following diversity indexes: Shannon-Wiener diversity index $\left(H^{\prime}\right)$ using the Ecological Methodology 5.1 software (Krebs, 1999); Margalef's richness index $\left(D_{m g}\right)$ using PAST 1.90 software (Hammer et al., 2001), and Pielou's evenness index $(J)$. The relative abundances $(p i)$ of Neotropical and exotic species were also compared between sampled years in each area by the Adjusted Wald Method (free analysis available at http://www.measuringusability. com/wald.htm).

Climatic data (mean temperature; relative humidity; mean and total precipitation; and luminosity), daily measures of 30 days prior to the collection in the field, were obtained from the UNICENTRO meteorological station (Campus CEDETEG), located at about eight kilometers of the collection areas. Test of normality of distribution for all data was performed using Shapiro-Wilk $(W)$ normality test. Afterwards, seasonal differences within a year were obtained performing a Mann-Whitney U test, and pairwise differences between seasons from sampled years for each climatic data were tested using nonparametric KruskalWallis ANOVA. Pearson product-moment correlation $(r)$ between species abundance and climatic variation matrices were also performed. All these statistical tests were realized in Statistica 7.0 software (Statsoft, Inc.).

\section{Results and Discussion}

A total of 3,491 individuals $(N)$ and 58 species $(S)$ were collected, 7 exotic and 51 indigenous of the Neotropical region (Tables 1 to 4). Among the 58 species, 31 had their first record in the Paraná state, Brazil (revision of Gottschalk et al., 2008). The tripunctata group had the higher richness (Table 2). A relatively low mean of the total $\mathrm{N}$ per trap $\left(N_{T}\right)$ was obtained from both areas combined $\left(N_{T}=9.09\right)$ when compared with other Drosophilidae assemblage from southern Brazil $\left(N_{T}>90\right.$ - Gottschalk et al., 2007; Döge et al., 2008; Poppe et al., 2012). This could be a result of the climatic conditions of these highland Araucaria Forest fragments in the sampled years, such as: higher annual relative humidity and precipitation, winters with negative temperatures, severe hoar-frosts, mean temperature in the warmer months below $21^{\circ} \mathrm{C}$, and mean annual temperature below $17{ }^{\circ} \mathrm{C}$ (data from UNICENTRO climate station, Guarapuava-PR). These conditions are not found altogether in any other forest area studied in the southern Brazil (abovementioned works). We found higher $S$ when compared to urbanized and rural areas of Pampa Biome, in southernmost Brazil (Poppe et al., 2012).

Medeiros and Klaczko (2004) analyzed the drosophilid communities from three different areas regarding climatic

Table 1. List of the indigenous Neotropical Drosophila species of the Drosophila subgenus, excluding tripunctata group species (Table 2) and ungrouped and Sophophora subgenus species (Table 3), with their absolute abundances, from collections in two forest fragments in southern Brazil in the years of 2006 and 2008 (PMA - Parque Municipal das Araucárias; FBL - Fazenda Brandalise).

\begin{tabular}{|c|c|c|c|c|c|c|c|c|c|}
\hline & \multicolumn{2}{|c|}{ PMA } & \multicolumn{2}{|c|}{ FBL } & & \multicolumn{2}{|c|}{ PMA } & \multicolumn{2}{|c|}{ FBL } \\
\hline & 2006 & 2008 & 2006 & 2008 & & 2006 & 2008 & 2006 & 2008 \\
\hline Subgenus Drosophila & & & & & - mesophragmatica & & & & \\
\hline - annulimana & & & & & D. mesophragmatica ${ }^{1 *}$ & 0 & 8 & 0 & 2 \\
\hline D. annulimana ${ }^{1 *}$ & 3 & 2 & 5 & 3 & - guaramuпu & & & & \\
\hline D. $\operatorname{arassari}^{2 *}$ & 1 & 11 & 1 & 6 & D. griseolineata $^{1}$ & 0 & 1 & 2 & 0 \\
\hline - bromeliae & & & & & D. guaraja $^{10}$ & 2 & 19 & 7 & 2 \\
\hline D. bromelioides ${ }^{2 *}$ & 2 & 5 & 0 & 1 & D. maculifrons $^{1}$ & 11 & 13 & 5 & 0 \\
\hline - calloptera & & & & & - guarani & & & & \\
\hline D. calloptera ${ }^{3 *}$ & 0 & 1 & 0 & 0 & D. guaru $^{6 *}$ & 3 & 9 & 2 & 20 \\
\hline - caponei & & & & & D. ornatifrons ${ }^{1}$ & 4 & 22 & 6 & 6 \\
\hline D. caponei ${ }^{2 *}$ & 1 & 0 & 1 & 0 & - pallidipennis & & & & \\
\hline - cardini & & & & & D. pallidipennis ${ }^{6}$ & 8 & 3 & 6 & 1 \\
\hline D. cardini $^{4}$ & 1 & 45 & 1 & 20 & - peruviana & & & & \\
\hline D. neocardini ${ }^{5}$ & 4 & 0 & 22 & 1 & D. peruviana ${ }^{1 *}$ & 9 & 0 & 0 & 0 \\
\hline D. polymorpha 6 & 95 & 158 & 37 & 83 & - repleta & & & & \\
\hline - coffeata & & & & & D. fascioloides ${ }^{6}$ & 0 & 1 & 0 & 0 \\
\hline D. coffeata ${ }^{7 *}$ & 1 & 0 & 0 & 0 & D. hydei ${ }^{11 *}$ & 0 & 1 & 1 & 0 \\
\hline D. fuscolineata ${ }^{8 *}$ & 1 & 1 & 0 & 1 & D. $m o j u^{9 *}$ & 1 & 2 & 0 & 4 \\
\hline - dreyfusi & & & & & D. onca ${ }^{6}$ & 0 & 2 & 0 & 0 \\
\hline D. camargoi $^{9 *}$ & 2 & 2 & 0 & 0 & repleta group & 0 & 0 & 5 & 0 \\
\hline D. dreyfusi ${ }^{6 *}$ & 7 & 0 & 1 & 1 & Total 1 (T1) & 156 & 306 & 102 & 151 \\
\hline
\end{tabular}

*Species with first record of collection in Paraná state, Brazil; ${ }^{1}$ Duda (1927); ${ }^{2}$ Pavan and da Cunha (1947); ${ }^{3}$ Schiner (1868); ${ }^{4}$ Sturtevant (1916); ${ }^{5}$ Streisinger (1946); ${ }^{6}$ Dobzhansky and Pavan (1943); ${ }^{7}$ Williston (1896); ${ }^{8}$ Duda (1925); ${ }^{9}$ Pavan (1950); ${ }^{10}$ King (1947); ${ }^{11}$ Sturtevant (1921). 
Table 2. List of the indigenous Neotropical Drosophila species of tripunctata group (with their absolute abundances) sampled in two forest fragments in southern Brazil in the years of 2006 and 2008 (PMA - Parque Municipal das Araucárias; FBL - Fazenda Brandalise).

\begin{tabular}{|c|c|c|c|c|c|c|c|c|c|}
\hline & \multicolumn{2}{|c|}{ PMA } & \multicolumn{2}{|c|}{ FBL } & & \multicolumn{2}{|c|}{ PMA } & \multicolumn{2}{|c|}{ FBL } \\
\hline & 2006 & 2008 & 2006 & 2008 & & 2006 & 2008 & 2006 & 2008 \\
\hline \multicolumn{10}{|l|}{ Subgenus Drosophila } \\
\hline - tripunctata & & & & & D. mediopunctata ${ }^{3}$ & 3 & 69 & 3 & 58 \\
\hline D. addisoni* ${ }^{1 *}$ & 5 & 4 & 2 & 3 & D. mediostriata & 12 & 0 & 7 & 0 \\
\hline D. nappae ${ }^{2 *}$ & 2 & 0 & 0 & 0 & D. morena $^{4 *}$ & 3 & 2 & 0 & 1 \\
\hline D. bandeirantorum ${ }^{3}$ & 10 & 8 & 6 & 2 & D. nigricincta ${ }^{4 *}$ & 2 & 0 & 0 & 0 \\
\hline D. bifilum $^{4 *}$ & 4 & 0 & 1 & 0 & D. paraguayensis ${ }^{6 *}$ & 16 & 3 & 8 & 1 \\
\hline D. bipunctata ${ }^{5 *}$ & 4 & 0 & 0 & 0 & D. platitarsus ${ }^{4 *}$ & 1 & 0 & 0 & 0 \\
\hline D. divisa ${ }^{6 *}$ & 0 & 0 & 0 & 1 & D. prosimilis ${ }^{6 *}$ & 7 & 3 & 3 & 0 \\
\hline D. mediocris ${ }^{4 *}$ & 1 & 0 & 0 & 0 & D. pruinifacies ${ }^{4 *}$ & 4 & 0 & 1 & 0 \\
\hline D. medioimpressa ${ }^{4 *}$ & 6 & 0 & 3 & 0 & D. trifilum $^{4 *}$ & 0 & 0 & 1 & 0 \\
\hline D. mediopicta ${ }^{4 *}$ & 4 & 26 & 3 & 4 & Total 2 (T2) & 84 & 115 & 38 & 70 \\
\hline
\end{tabular}

*Species with first record of collection in Paraná state, Brazil; ${ }^{1}$ Pavan (1950); ${ }^{2}$ Vilela et al (2004); ${ }^{3}$ Dobzhansky and Pavan (1943); ${ }^{4}$ Frota-Pessoa (1954); ${ }^{5}$ Patterson (1943); ${ }^{6}$ Duda (1927); ${ }^{7}$ Duda (1925).

Table 3. List of the indigenous Neotropical Drosophila species, excluding the grouped species of subgenus Drosophila (Table 1) and tripunctata group species (Table 2), with their absolute abundances, from collections in two forest fragments in southern Brazil in the years of 2006 and 2008 (PMA - Parque Municipal das Araucárias; FBL - Fazenda Brandalise).

\begin{tabular}{|c|c|c|c|c|}
\hline & \multicolumn{2}{|c|}{ PMA } & \multicolumn{2}{|c|}{ FBL } \\
\hline & 2006 & 2008 & 2006 & 2008 \\
\hline \multicolumn{5}{|l|}{ Subgenus Drosophila } \\
\hline \multicolumn{5}{|l|}{ Ungrouped } \\
\hline D. impudica ${ }^{1 *}$ & 0 & 0 & 1 & 0 \\
\hline D. tuchaua ${ }^{2 *}$ & 2 & 0 & 3 & 0 \\
\hline \multicolumn{5}{|c|}{ Subgenus Sophophora } \\
\hline \multicolumn{5}{|c|}{ - saltans } \\
\hline D. prosaltans ${ }^{1}$ & 0 & 0 & 0 & 1 \\
\hline D. sturtevanti ${ }^{1}$ & 7 & 9 & 4 & 2 \\
\hline saltans group & 0 & 0 & 2 & 0 \\
\hline \multicolumn{5}{|l|}{ - willistoni } \\
\hline D. bocainensis ${ }^{3}$ & 0 & 0 & 0 & 1 \\
\hline D. capricorni $^{4}$ & 12 & 5 & 6 & 6 \\
\hline willistoni subgroup & 152 & 247 & 945 & 64 \\
\hline Total 3 (T3) & 173 & 261 & 961 & 74 \\
\hline $\mathrm{T} 1+\mathrm{T} 2+\mathrm{T} 3$ & 413 & 682 & 1,101 & 295 \\
\hline
\end{tabular}

$\mathrm{T} 1=$ specimes total of Table $1 . \mathrm{T} 2=$ specimes total of Table 2. T3 $=$ specimes total of this table; $*$ Species with first record of collection in Paraná state, Brazil; ${ }^{1}$ Duda (1927); ${ }^{2}$ Pavan (1950); ${ }^{3}$ Pavan and da Cunha (1947); ${ }^{4}$ Dobzhansky and Pavan (1943).

and geomorphological features. One of them, Serra do Japi, an altitudinal forest located in São Paulo state, southeast of Brazil, is a region with similar altitude and climatic conditions compared to the fragments studied here. In this area, these authors performed collections with sampling effort compatible with our work and they found several results coincident with the data obtained here, although they only identified males because aedeagus morphology is the diagnostic character for several Drosophila species. They obtained $N(4,018), S(57)$, higher richness in the tripunctata group (22 in a total of 57 species) and a general drosophilid assemblage composition very similar to ours, specially regarding the high subgroup willistoni and low D. simulans absolute abundances (Tables 3 and 4, respectively). High abundance of subgroup willistoni has been considered as characteristic of forested areas (Martins, 1987, 2001; Saavedra et al., 1995). A very conspicuous difference between our data and the drosophilid assemblage from Serra do Japi is related to absolute abundance of each exotic species, which were very low in the work of Medeiros and Klaczko (2004), and were noteworthy in the present work, such as the case of D. kikkawai (Table 4).

Different works on forest fragments from southern Brazil (Gottschalk et al., 2007; Döge et al., 2008; Poppe et al., 2012) detected high absolute abundance of the exotic species $D$. simulans, which is opposed to what was found in Medeiros and Klaczko (2004) and in this study (this species is not among the five most abundant in any of the sampled areas here). The high abundance observed for $D$. simulans in Brazilian natural environments was suggested to be due to the "naturalization" of this species (Dobzhansky and Pavan, 1950; Pavan, 1959). However, according to Gottschalk et al. (2007), D. simulans distribution pattern in urban gradients suggests that perhaps this species cannot establish itself so easily in the Atlantic Forest.

The comparison of climatic data among seasons of the same year showed significant differences $(p<0.01)$ for almost all measures, excepting total precipitation in 2008. These results indicated that the seasons within a year were climatic distinct. The pairwise comparisons between seasons from different years revealed significant differences $(\mathrm{p}<0.01)$ in the relative humidity in the autumn, winter and spring, in luminosity in the summer and spring, in total 
Table 4. List of the exotic Drosophilidae species (with their absolute abundances) sampled in two forest fragments in southern Brazil in the years of 2006 and 2008 (PMA - Parque Municipal das Araucárias; FBL - Fazenda Brandalise).

\begin{tabular}{|c|c|c|c|c|}
\hline & \multicolumn{2}{|c|}{ PMA } & \multicolumn{2}{|c|}{ FBL } \\
\hline & 2006 & 2008 & 2006 & 2008 \\
\hline \multicolumn{5}{|l|}{ Genus Drosophila } \\
\hline \multirow{2}{*}{\multicolumn{5}{|c|}{$\begin{array}{l}\text { Subgenus Dorsilopha } \\
\text { - busckii }\end{array}$}} \\
\hline & & & & \\
\hline D. busckii & 0 & 1 & 3 & 1 \\
\hline \multicolumn{5}{|l|}{ Subgenus Drosophila } \\
\hline \multicolumn{5}{|l|}{ - immigrans } \\
\hline D. immigrans $^{2}$ & 3 & 10 & 2 & 4 \\
\hline \multirow{2}{*}{\multicolumn{5}{|c|}{$\begin{array}{l}\text { Subgenus Sophophora } \\
\text { - melanogaster }\end{array}$}} \\
\hline & & & & \\
\hline D. ananassae ${ }^{3}$ & 3 & 0 & 0 & 0 \\
\hline D. $k i k k a w a i^{4}$ & 52 & 692 & 39 & 82 \\
\hline D. simulans ${ }^{5}$ & 52 & 30 & 9 & 1 \\
\hline \multicolumn{5}{|l|}{ Genus } \\
\hline \multicolumn{5}{|l|}{ Scaptodrosophila } \\
\hline \multicolumn{5}{|l|}{ - latifasciaeformis } \\
\hline S. latifasciaeformis ${ }^{6}$ & 1 & 4 & 1 & 0 \\
\hline \multicolumn{5}{|l|}{ Genus Zaprionus } \\
\hline \multicolumn{5}{|l|}{ - vittiger } \\
\hline Z. indianus ${ }^{7}$ & 0 & 3 & 7 & 0 \\
\hline Total & 111 & 740 & 61 & 88 \\
\hline
\end{tabular}

precipitation in autumn and winter, and temperature in spring. Therefore, seasons also presented some differences between years. In this context, changes in the drosophilid assemblages were compared to climatic differences. Firstly, our results showed that about $72 \%$ of the species were poorly collected (less than a total of 20 sampled individuals from all collections), which severely restricted the reliability of any correlation between drosophlid assemblage and climatic data, specially using seasonal collections. Thus, significant seasonal correlations between years and areas of collection of drosophilids with climatic data were considered only for species that had $\mathrm{N} \geq 30$ in at least one area (D. cardini, D. kikkawai, D. mediopicta, D. mediopunctata, $D$. polymorpha, D. simulans and willistoni subgroup). The abundance of $D$. polymorpha was positively correlated with temperature $(\mathrm{r}=0.7417 ; \mathrm{p}<0.05)$ and luminosity $(\mathrm{r}=0.8299 ; \mathrm{p}<0.05)$. No other correlation was detected between any species and climatic data.

Therefore, changes in the drosophilid assemblages, in general, cannot be related to the climatic alterations detected between years. However, is noteworthy to point out some consistent changes for a couple of species, such as: D. polymorpha was collected with higher abundance in the warmer seasons (summer and spring), in agreement with the correlation analysis above; the exotic species D. kikkawai and D. simulans were also more abundant in warmer seasons; D. mediopunctata was more abundant in
2008 autumn and winter in both areas; and the subgroup willistoni was more representative in summer and autumn in PMA and in summer in FBL (Table 1-SM - supplementary material), in agreement with several authors (Patterson, 1943; Dobzhansky and Pavan, 1950; Franck and Valente, 1985; Toni et al., 2007).

Among the species that had $\mathrm{N} \geq 30$ in at least one area, the exotic species $D$. kikkawai and $D$. simulans exhibited variation of more than $80 \%$ in abundance between areas, with PMA presenting higher abundance (in 2008 for D. kikkawai $-\mathrm{N}=692$, and in 2006 and 2008 for D. simulans $-\mathrm{N}=52$ and $\mathrm{N}=30$, respectively; Table 4). Among the Neotropical indigenous species, the subgroup willistoni showed differences of more than $70 \%$ between areas (Table 3), with higher abundance for FBL in 2006 $(\mathrm{N}=945)$ and for PMA in $2008(\mathrm{~N}=247)$.

Regarding the ecological indexes, PMA in 2006 ( $H^{\prime}$ $=2.601$ ) and the autumn in 2006 in both areas (PMA: $H^{\prime}=2.941$; FBL: $\left.H^{\prime}=2.626\right)$ had higher diversity than already detected, but in general, the diversity indexes $\left(H^{\prime}\right)$ were mostly similar (but sometimes higher than) to those found in other works (Silva et al., 2005a; Tidon, 2006; Toni et al., 2007; Gottschalk et al., 2007; Bizzo et al., 2010; Schmitz et al., 2010; Poppe et al., 2012). No seasonal pattern was detected in both areas. PMA showed higher values than FBL for all three ecological indexes (Table 5), probably because PMA is a conservation unit with different habitats available (forest, swamp and field) and FBL present higher disturbance because of intense extractive activity (mate and Araucaria seeds). Also, the accentuated decrease of subgroup willistoni in 2008 in FBL (Table 3), without correlation with any climatic factor sampled, could be an indication of an increase in human activities impact in this area.

In opposition to the very distinct diversity indexes between fragments, the richness indexes $\left(D_{m g}\right)$ were very similar. Thus, we proposed that this could be because FBL has a much larger and less fragmented area than PMA. The work of Gibbs and Stanton (2001) support this hypothesis as they detected that species richness of beetle community in the state of New York, USA, was higher in contiguous forest sites than in fragmented forest areas. Therefore, habitat availability and conservation state could be responsible for the considerable differences in diversity but not in richness between areas, with richness being under a balance among area size versus habitat availability and conservation state of the fragments.

Exotic species abundance and richness were higher in PMA than in FBL (Figure 1), although the first is a conservation unit. Regarding exotic species, one result that stands out is the low frequency of Zaprionus indianus. In two years of collection, only 10 individuals were captured from both areas (Table 4). This species was recently introduced in the southeast of Brazil (Vilela, 1999) and became a highly abundant species in natural as well as in urbanized environments (De Toni et al., 2001; Ferreira and Tidon, 2005; Silva et al., 2005a, b; Gottschalk et al., 2007). However, low abundance for this species was also 
Table 5. Absolute $(N)$ and relative ( $p i$; percentage in parentheses) abundances, absolute richness $(S)$ of indigenous Neotropical and exotic Drosophilidae species, and ecological indexes $\left(H^{\prime}=\right.$ Shannon-Wiener's diversity index; $D_{m g}=$ Margalef's richness index; $J=$ Pielou's evenness index) from two highland Araucaria Forest fragments (PMA - Parque Municipal das Araucárias; FBL - Fazenda Brandalise) in southern Brazil in the years of 2006 and 2008.

\begin{tabular}{|c|c|c|c|c|}
\hline \multirow{4}{*}{ Neotropical } & \multicolumn{2}{|c|}{$\operatorname{PMA}(S=51 ; N=1,946)$} & \multicolumn{2}{|c|}{ FBL $(S=46 ; N=1,545)$} \\
\hline & 2006 & 2008 & 2006 & 2008 \\
\hline & \multicolumn{2}{|c|}{$(S=44 ; N=1,095)$} & \multicolumn{2}{|c|}{$(S=40 ; N=1,396)$} \\
\hline & 38 & 29 & 32 & 26 \\
\hline$N(p i)$ & $413(78.82)$ & $682(47.96)$ & $1,101(94.75)$ & $295(77.02)$ \\
\hline Exotic & \multicolumn{2}{|c|}{$(S=7 ; N=851)$} & \multicolumn{2}{|c|}{$(S=6 ; N=149)$} \\
\hline $\mathrm{S}$ & 5 & 6 & 6 & 4 \\
\hline$N(p i)$ & $111(21.18)$ & $740(52.84)$ & $61(5.25)$ & $88(22.98)$ \\
\hline $\mathrm{H}^{\prime}$ & 2.601 & 1.871 & 1.038 & 2.265 \\
\hline Summer & 1.345 & 1.101 & 0.693 & 1.128 \\
\hline Autumn & 2.941 & 1.587 & 2.626 & 1.562 \\
\hline Winter & 2.168 & 2.218 & 2.307 & 1.862 \\
\hline Spring & 1.605 & 2.027 & 1.979 & 1.977 \\
\hline Total & \multicolumn{2}{|c|}{2.221} & \multicolumn{2}{|c|}{1.592} \\
\hline $\mathrm{D}_{\mathrm{mg}}$ & 6.708 & 4.683 & 5.996 & 4.876 \\
\hline Summer & 1.947 & 2.481 & 2.724 & 2.561 \\
\hline Autumn & 6.224 & 3.053 & 5.031 & 2.909 \\
\hline Winter & 3.114 & 3.319 & 3.607 & 2.583 \\
\hline Spring & 2.546 & 2.667 & 2.817 & 2.784 \\
\hline Total & \multicolumn{2}{|c|}{6.602} & \multicolumn{2}{|c|}{6.128} \\
\hline $\mathrm{J}$ & 0.692 & 0.526 & 0.285 & 0.666 \\
\hline Summer & 0.561 & 0.381 & 0.231 & 0.427 \\
\hline Autumn & 0.841 & 0.549 & 0.850 & 0.577 \\
\hline Winter & 0.942 & 0.783 & 0.962 & 0.777 \\
\hline Spring & 0.608 & 0.790 & 0.952 & 0.796 \\
\hline Total & \multicolumn{2}{|c|}{0.565} & \multicolumn{2}{|c|}{0.416} \\
\hline
\end{tabular}

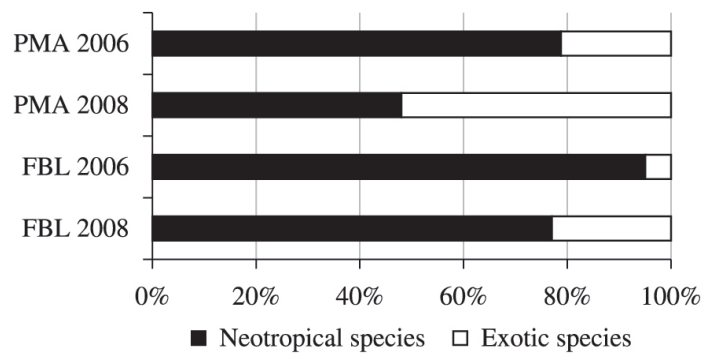

Figure 1. Relative abundance (pi) of the indigenous Neotropical and exotic Drosophilidae species sampled in two forest fragments in southern Brazil in the years of 2006 and 2008 (PMA - Parque Municipal das Araucárias; FBL Fazenda Brandalise).

found in transition areas between Atlantic Forest and Pampa (Hochmüller et al., 2010) and in Pampa (Poppe et al., 2012), both from the interior of the Rio Grande do Sul state, southern Brazil. Poppe et al. (2012) suggested that the $Z$. indianus scarcity detected would be because this region is closer to the southernmost limit of distribution for this species, being therefore composed of marginal populations that are submitted to suboptimal conditions and limited by climatic features, such as lower temperatures. Our results also indicated that the limiting factor for the establishment of $Z$. indianus in highland Araucaria Forest is probably lower temperatures, mostly because all ten collected individuals were obtained in the summer.

In conclusion, although FBL has higher forest coverage, approximately four times the forest coverage of PMA, being a less fragmented area, PMA is more heterogeneous in habitat composition, which can provide more microhabitats and support higher species diversity in this area, demonstrating that conservation units are important for biodiversity. Moreover, PMA is a conservation unit since 1991 and has been effectively preserved and conserved, while FBL exhibit high antrophic extractive activity (mainly mate and Araucaria seeds) that could affect species distribution and occurrence in this area. However, the fact that FBL is larger, less fragmented and more distant of Guarapuava city limits than PMA, could be providing a better resource exploration opportunity for the drosophilid community, compensating the antrophic disturbance in this area, and this unbalance in both areas could explain the similar richness indexes $\left(D_{m g}\right)$ detected. This way, the size of the preservation area and/ or connection with other fragments should be considered for the stablishment of conservation units. 
Therefore, the highland Araucaria Forest fragments sampled in this work had very similar Drosophilidae assemblages, and were also similar to other altitudinal forest assemblage from Serra do Japi, southeastern Brazil (Medeiros and Klaczko, 2004). However, despite the high abundance of Neotropical species (mainly of the subgroup willistoni), the fragments studied here differ in quality from the Serra do Japi because the high abundance of exotic species $D$. kikkawai, suggesting that both highland Araucaria Forest fragments studied are in intermediate state of conservation.

\section{Acknowledgements}

We are thankful to A Scherloski, DP Simão, EC Gustani, JP Pericolo, K dos Santos, KCB Oliveira, NS Alves, NP Heinz, PT Rodrigues and VF Lopes for technical assistance in the collections. To Dr MO Moura for help with the ecological analyses. To Dra N Shindo for translation of the manuscript. Funds were provided by: SETI/Fundação Araucária (R. P. Mateus); Financiadora de Estudos e Projetos - FINEP; Coordenação de Aperfeiçoamento de Pessoal de Nível Superior - CAPES (R. Cavasini Master's Fellowship); Conselho Nacional de Desenvolvimento Científico e Tecnológico - CNPq (M. L. T. Buschini, grant number 477696/2004-0); and Universidade Estadual do Centro-Oeste, UNICENTRO.

\section{References}

ALFORD, RA. and RICHARDS, ESJ., 1999. Global amphibian declines: A problem in applied ecology. Annual Review of Ecology and Systematics, vol. 30, no. 1, p. 133-165. http://dx.doi. org/10.1146/annurev.ecolsys.30.1.133.

AVONDET, JL., BLAIR, RB., BERG, DJ. and EBBERT, MA., 2003. Drosophila (Diptera: Drosophilidae) response to changes in ecological parameters across an urban gradient. Environmental Entomology, vol. 32, no. 2, p. 347-358. http:// dx.doi.org/10.1603/0046-225X-32.2.347.

BAWA, KS., KRESS, WJ., NADKARNI, NM., LELE, S., RAVEN, PH., JANZEN, DH., LUGO, AE., ASHTON, PS. and LOVEJOY, TE., 2004. Tropical ecosystems into the 21st century. Science, vol. 306, no. 5694, p. 227-228. http://dx.doi.org/10.1126/ science.306.5694.227b. PMid:15472058

BIZZO, L., GOTTSCHALK, MS., DE TONI, DC. and HOFMANN, PRP., 2010. Seasonal dynamics of a drosophilid (Diptera) assemblage and its potencial as bioindicator in open environments. Iheringia. Série Zoológica, vol. 100, no. 3, p. 185-191.

Brasil. Ministério do Meio Ambiente. Instituto Brasileiro do Meio Ambiente e dos Recursos Naturais Renováveis, 2010. Monitoramento do desmatamento nos biomas brasileiros por satélite. Acordo de cooperação técnica MMA/IBAMA. Monitoramento do bioma mata atlântica 2002 a 2008. Brasília: MMA/IBAMA. Available from: $<$ http://siscom.ibama.gov.br/monitorabiomas/mataatlantica/ RELATORIO PMDBBS MATA ATLANTICA 2002-2008. pdf $>$. Access in: 20 Oct. 2012.

BUSCHINI, MLT., 2006. Species diversity and community structure in trap-nesting bees in Southern Brazil. Apidologie, vol. 37, no. 1, p. 58-66. http://dx.doi.org/10.1051/apido:2005059.
DE TONI, DC., HOFMANN, PRP. and VALENTE, VLS., 2001. First record of Zaprionus indianus (Diptera, Drosophilidae) in the State of Santa Catarina, Brazil. Biotemas, vol. 14, no. 1, p. 71-85.

DOBZHANSKY, TH. and PAVAN, C., 1950. Local and seasonal variation in frequencies of species of Drosophila in Brazil. Journal of Animal Ecology, vol. 19, no. 1, p. 1-14. http://dx.doi. org/10.2307/1566.

DÖGE, JS., VALENTE, VLS. and HOFMANN, PRP., 2008. Drosophilids (Diptera) from an Atlantic Forest Area in Santa Catarina, Southern Brazil. Revista Brasileira de Entomologia, vol. 52, no. 4, p. 615-624. http://dx.doi.org/10.1590/S008556262008000400013 .

FERREIRA, LB. and TIDON, R., 2005. Colonizing potential of Drosophilidae (Insecta, Diptera) in environments with different grades of urbanization. Biodiversity and Conservation, vol. 14, no. 8, p. 1809-1821. http://dx.doi.org/10.1007/s10531-004-0701-4.

FRANCK, G. and VALENTE, VLS., 1985. Study on the flutuation in Drosophila populations of Bento Gonçalves, RS, Brasil. Revista Brasileira de Biologia = Brazilian Journal of Biology, vol. 45, no. 1-2, p. 133-141.

FREIRE-MAIA, N. and PAVAN, C., 1949. Introdução ao estudo da drosófila. Cultus, vol. 1, no. 5, p. 3-66.

FROTA-PESSOA, O., 1954. Revision of the tripunctata group of Drosophila with description of fifteen new species (Drosophilidae, Diptera). Arquivos do Museu Paranaense, vol. 10, no. 6, p. 253-330.

GIBBS, JP. and STANTON, EJ., 2001. Habitat Fragmentation and Arthropod Community Change: Carrion Beetles, Phoretic Mites, and Flies. Ecological Applications, vol. 11, no. 1, p. 7985. http://dx.doi.org/10.1890/1051-0761(2001)011[0079:HFA $\mathrm{ACC}] 2.0 . \mathrm{CO} ; 2$.

GOTTSCHALK, MS., DE TONI, DC., VALENTE, VLS. and HOFMANN, PRP., 2007. Changes in Brazilian Drosophilidae (Diptera) assemblages across an urbanisation gradient. Neotropical Entomology, vol. 36, no. 6, p. 848-862. http://dx.doi.org/10.1590/ S1519-566X2007000600005. PMid:18246258

GOTTSCHALK, MS., HOFMANN, PRP. and VALENTE, VLS., 2008. Diptera, Drosophilidae: historical occurrence in Brazil. Check List, vol. 4, no. 4, p. 485-518.

HAMMER, O., HARPER, DAT. and RYAN, PD., 2001. PAST: paleontological statistics software package for education and data analysis. Palaeontologia Electronica, vol. 4, no. 1, p. 1-9.

HOCHMÜLLER, CJ., LOPES-DA-SILVA, M., VALENTE, VLS. and SCHMITZ, HJ., 2010. The drosophilid fauna (Diptera, Drosophilidae) of the transition between the Pampa and Atlantic Forest Biomes in the state of Rio Grande do Sul, southern Brazil: first records. Papéis Avulsos de Zoologia, vol. 50, no. 19, p. 285-295.

KREBS, CJ., 1999. Ecological methodology. 2nd ed. Menlo Park: Addison Wesley Educational Publishers. 620 p.

MARTINS, M., 1987. Variação espacial e temporal de algumas espécies e grupos de Drosophila (Diptera) em duas reservas de matas isoladas, nas vizinhanças de Manaus (Amazonas, Brasil). Boletim do Museu Paraense Emílio Goeldi, vol. 3, no. 2, p. 195-218.

MARTINS, M., 2001. Drosophilid fruit-fly guilds in forest fragments. In BIERREGARD JUNIOR, RO., GASCON, C., LOVEJOY, TE. and MESQUITA, R. (Eds.). Lessons from Amazonia: The ecology and conservation of a fragmented forest. New Haven: Yale University Press. p. 175-186. 
MATA, RA., MCGEOCH, M. and TIDON, R., 2008. Drosophilid assemblages as a bioindicator system of human disturbance in the Brazilian Savanna. Biodiversity and Conservation, vol. 17, no. 12, p. 2899-2916. http://dx.doi.org/10.1007/s10531-008-9403-7.

MATA, RA., MCGEOCH, M. and TIDON, R., 2010. Drosophilids (Insecta, Diptera) as tools for conservation biology. Brazilian Journal of Nature Conservation, vol. 8, no. 1, p. 60-65. http:// dx.doi.org/10.4322/natcon.00801009.

MEDEIROS, HF. and KLACZKO, LB., 1999. A weakly biased Drosophila trap. Drosophila Information Service, vol. 82, p. 100-102.

MEDEIROS, HF. and KLACZKO, LB., 2004. How many species of Drosophila (Diptera, Drosophilidae) remain to be described in the forests of São Paulo, Brazil? Species lists of three forest remnants. Biota Neotropica, vol. 4, no. 1, p. 1-12. http://dx.doi. org/10.1590/S1676-06032004000100005.

MYERS, N., MITTERMEIER, RA., MITTERMEIER, CG., DA FONSECA, GA. and KENT, J., 2000. Biodiversity hotspots for conservation priorities. Nature, vol. 403, no. 6772, p. 853-858. http://dx.doi.org/10.1038/35002501. PMid:10706275

PARSONS, PA., 1991. Biodiversity conservation under global climatic change: the insect Drosophila as a biological indicator? Global Ecology and Biogeography, vol. 1, no. 3, p. 77-83. http:// dx.doi.org/10.2307/2997493.

PATTERSON, JT., 1943. The Drosophilidae of the Southwest. The University of Texas Publication, vol. 4313, p. 7-216.

PAVAN, C., 1959. Relações entre populações de Drosophila e o meio ambiente. Boletim da Faculdade de Filosofia. Ciências e Letras da USP, vol. 11, no. 221, p. 1-81.

POPPE, JL., VALENTE, VLS. and SCHMITZ, HJ., 2012. Structure of Drosophilidae Assemblage (Insecta, Diptera) in Pampa Biome (São Luiz Gonzaga, RS). Papéis Avulsos de Zoologia, vol. 52, no. 16, p. 185-196.

POWELL, JR., 1997. Progress and prospects in evolutionary biology: the Drosophila model. New York: Oxford University Press. $562 \mathrm{p}$.

RIBEIRO, MC., METZGER, JP., MARTENSEN, AC., PONZONI, FJ. and HIROTA, MM., 2009. The Brazilian Atlantic Forest: How much is left, and how is the remaining forest distribution? Implications for conservation. Biological Conservation, vol. 142, no. 6, p. 1141-1153. http://dx.doi.org/10.1016/j.biocon.2009.02.021.

SAAVEDRA, CCR., CALLEGARI-JACQUES, SM., NAPP, M. and VALENTE, VLS., 1995. A descriptive and analytical study of four Neotropical Drosophilid communities. Journal of Zoological Systematics and Evolutionary Research, vol. 33, no. 2, p. 62-74. http://dx.doi.org/10.1111/j.1439-0469.1995.tb00210.x.
SCHMITZ, HJ., HOFMANN, PRP. and VALENTE, VLS., 2010. Assemblages of drosophilids (Diptera, Drosophilidae) in mangrove forests: community ecology and species diversity. Iheringia. Série Zoologia, vol. 100, no. 2, p. 133-140. http://dx.doi.org/10.1590/ S0073-47212010000200008.

SILVA, NM., FANTINEL, CC., VALENTE, VLS. and VALIATI, VH., 2005a. Population dynamics of the invasive species Zaprionus indianus (Gupta) (Diptera: Drosophilidae) in communities of drosophilids of Porto Alegre city, souther of Brazil. Neotropical Entomology, vol. 34, no. 3, p. 363-374. http://dx.doi.org/10.1590/ S1519-566X2005000300002.

SILVA, NM., FANTINEL, CC., VALENTE, VLS. and VALIATI, VH., 2005b. Ecology of colonizing populations of the figfly Zaprionus indianus (Diptera, Drosophilidae) in Porto Alegre, Southern Brazil. Iheringia. Série Zoológica, vol. 95, no. 3, p. 233-240. http://dx.doi.org/10.1590/S0073-47212005000300002.

TIDON, R., 2006. Relationships between drosophilids (Diptera, Drosophilidae) and the environment in two contrasting tropical vegetations. Biological Journal of the Linnean Society, vol. 87, no. 2, p. 233-247. http://dx.doi.org/10.1111/j.1095-8312.2006.00570.x.

TONI, DC., GOTTSCHALK, MS., CORDEIRO, J., HOFMANN, PP. and VALENTE, VLS., 2007. Study of the Drosophilidae (Diptera) communities on Atlantic Forest islands of Santa Catarina State, Brazil. Neotropical Entomology, vol. 36, no. 3, p. 356-375. http:// dx.doi.org/10.1590/S1519-566X2007000300004. PMid:17710319

VAL, FC., 1982. The male genitalia of some Neotropical Drosophila: notes and illustrations. Papéis Avulsos de Zoologia, vol. 34, no. 27, p. 309-347.

VELOSO, HP., RANGEL FILHO, ALR. and LIMA, JCA., 1991. Classificação da vegetação brasileira, adaptada a um sistema universal. Rio de Janeiro: IBGE/Departamento de Recursos Naturais e Estudos Ambientais.

VILELA, CR., 1983. A revision of the Drosophila repleta species group (Diptera, Drosophilidae). Revista Brasileira de Entomologia, vol. 27 , no. 1, p. 1-114.

VILELA, CR., 1992. On the Drosophila tripunctata species group (Diptera, Drosophilidae). Revista Brasileira de Entomologia, vol. 36, no. 1, p. 197-221.

VILELA, CR., 1999. Is Zaprionus indianus Gupta, 1970 (Diptera, Drosophilidae) currently colonizing the Neotropical region? Drosophila Information Service, vol. 82, p. 37-39.

VILELA, CR. and BÄCHLI, G., 1990. Taxonomic studies on neotropical species of seven genera of Drosophilidae (Diptera). Mitteilungen der Schweizerische Entomologische Gesellschaft, vol. 63 , p. 1-332. 